\title{
Body growth description of male and female from three broilers strains in the hot climate
}

\section{Descrição do crescimento corporal de machos e fêmeas de três linhagens de frangos de corte em clima quente}

\author{
Dáphinne Cardoso Nagib do Nascimento ${ }^{1 *}$; Leilane Rocha Barros Dourado²; \\ Jefferson Costa de Siqueira ${ }^{3}$; Francisca das Chagas Fontenele de Albuquerque ${ }^{4}$; \\ Roberto Melo Marques ${ }^{4}$; Simara Marcia Marcato5; Nilva Kazue Sakomura6; \\ Leonardo Atta Farias ${ }^{2}$
}

\section{Highlights:}

The females had lower weights at maturity and higher maturity rates than the males. The Hubbard strain had the highest growth rate, followed by the Ross, and the Cobb. The Hubbard females showed the highest breast weight at 42 days old.

\begin{abstract}
To evaluate the growth of males and females from three broiler strains (Cobb 500, Ross 308, and Hubbard Flex) we used a completely randomized experimental design with a factorial arrangement (3 strains and 2 sexes) and six replicates of 60 birds each, 2160 chicks of both sexes in total followed for 56 days. Once a week, the birds from each pen were weighed to estimate the average weight. The sample birds were fasted for 24 hours, re-weighed, slaughtered, eviscerated, and dissected to obtain the breast, thigh and drumstick cuts. The fitted Gompertz equations were used for each strain, and sex, for the fasted weight, and the weight of breasts, thighs, and drumsticks. To verify the effect of strain on the Gompertz curve parameters we assessed the weight at maturity $(\mathrm{Wm})$, rate of maturing $(\mathrm{b})$, and the time at which maximum growth rate was attained $\left(t^{*}\right)$ for both sexes and verified the equivalence of parameters and identity of non-linear models. For the fasted weight the rate of maturing was very similar for all strains and sexes, but the Hubbard strain showed the highest $\mathrm{Wm}$ and $\mathrm{t}^{*}$. The $\mathrm{Wm}$ parameter was common for most cuts among the strains, and the Hubbard was the dominant strain with the highest $b$ parameter. All three parameters were similar for the male breast weight, and only one equation required adjustment to describe the breast weight growth for the three strains. Individually adjusted equations were necessary to describe the weight of drumsticks because females showed no similarity in any of the parameters for any strain.
\end{abstract}

Key words: Carcass yield. Genetic. Poultry industry.

1 Pós-Doutoranda, Programa de Pós-Graduação em Ciência Animal, Universidade Federal do Maranhão, UFMA, Chapadinha, MA, Brasil. E-mail: daphinnen@icloud.com

2 Profs., Universidade Federal do Piauí, UFPI, Bom Jesus, PI, Brasil. E-mail: leilane@ufpi.edu.br; leonardoatta@yahoo.com.br

3 Prof., UFMA, Chapadinha, MA, Brasil. E-mail: jc.siqueira@ufma.br

4 Discentes, Curso de Graduação em Zootecnia, UFPI, Bom Jesus, PI, Brasil. marta.albuquerque18@gmail.com; robertomelomarque@gmail.com

5 Prof ${ }^{a}$, Universidade Estadual de Maringá, UEM, Maringá, PR, Brasil. E-mail: simaramm@yahoo.com.br

6 Profa, Universidade Estadual Paulista "Julio De Mesquita Filho”, UNESP, Jaboticabal, SP, Brasil. E-mail: nilvasakomura@ gmail.com

* Author for correspondence 


\section{Resumo}

Para descrever o crescimento corporal de machos e fêmeas das linhagens de frango de corte Cobb 500, Ross 308 e Hubbard Flex, foram usados 2160 pintos de ambos os sexos, distribuídos em delineamento experimental inteiramente casualizado em arranjo fatorial (3 linhagens e 2 sexos) com seis repetições de 60 aves cada. Uma vez por semana as aves foram pesadas para estimar o peso médio. As aves selecionadas foram mantidas em jejum por $24 \mathrm{~h}$, pesadas novamente, abatidas, evisceradas e dissecadas para obtenção dos cortes de peito, coxas e sobrecoxas. Foram ajustadas as equações de Gompertz para cada linhagem, em cada sexo, para o peso em jejum, peso de peito, coxas e sobrecoxas. Para verificar o efeito de linhagem nos parâmetros das curvas de Gompertz, peso na maturidade $\left(\mathrm{W}_{\mathrm{m}}\right)$, taxa de maturação (b) e tempo em que a taxa máxima de crescimento é atingida ( $\left.\mathrm{t}^{*}\right)$, de cada característica avaliada dentro do sexo, testes foram conduzidos para verificar a igualdade de parâmetros e identidade de modelos não lineares. Para o peso em jejum, independentemente do sexo, o parâmetro $b$ foi comum entre essas as linhagens, sendo que Hubbard machos e fêmeas apresentou os maiores Wm e $t$ *. Para a maioria dos cortes o parâmetro Wm era comum entre as linhagens, sendo o Hubbard a linhagem precoce devido ao seu maior b, sobre as aves Ross e Cobb. Para o peso de peito em machos, o modelo mais apropriado foi o que todos os parâmetros eram semelhantes, exigindo o ajuste de apenas uma equação para descrever o crescimento das três linhagens. Para peso de sobrecoxas, as fêmeas Cobb, Ross e Hubbard não mostraram semelhança em nenhum dos parâmetros, sendo ajustadas equações individuais para cada linhagem.

Palavras-chave: Avicultura. Linhagens. Rendimento de carcaça.

\section{Introduction}

The broiler strains available on the market present high growth potential with specific attributes that depend on the genetic improvement of their conformation. The choice between different strains and sex should depend on the objective of the producers and the food industry, so faster weight gain and lower feed conversion are desirable for commercialization of live chickens. However, if the cuts are the priority, a broiler strain with high carcass yields and cuts should be selected.

Typical studies of different strains are carried out at specific ages or during narrow timeframes, providing information about economically important traits, e.g. feed intake and feed conversion during the evaluation period. However, some segments of the poultry production chain require information about the growth of the bird and its parts over time, to allow predicting the best time of slaughter to obtain a particular characteristic.

Growth curves are non-linear models that describe the weight of the bird or parts of the body over time that may vary depending on the species, lineage, sex, and nutrition (Aggrey, 2002).

Among the non-linear models applicable to animal production are the models of Brody, Richards, Von Bertalanffy, and Gompertz, the latter being widely used to describe the growth of birds; it is a relatively simple model with parameters permitting biological interpretation (Gous, Moran, Stilborn, Bradford, \& Emmans, 1999; Hancock, Bradford, Emmans, \& Gous, 1995).

Several food companies serve both the internal and external markets, producing whole birds with different weights, several types of cuts, e.g. breasts, wings, thighs, and drumsticks. It is important that these cuts are within the standard demanded by the consumer.

Accordingly, the knowledge of the specific growth curves of whole birds and cuts with respect to the lineage and sex is required to optimize age of slaughter and to maximize the production of whole carcasses or certain cuts. The objective of this study was to compare the growth curves of the body 
weight and the cuts (breasts, thighs, and drumsticks) of male and female broilers of three commercial strains (Cobb 500, Ross 308, and Hubbard Flex).

\section{Materials and Methods}

\section{Ethics statement}

The protocol $(056 / 14)$ was approved by the Ethics Committee on Animal Experimentation of the Federal University of Piauí (Piauí, Brazil).

\section{Birds and housing}

The experiment was carried out in March 11 through May 06, 2014, in the Poultry Sector of Technical College of Bom Jesus, Campus Professor Cinobelina Elvas, Federal University of Piauí (municipality of Bom Jesus, PI), located at 0904'26" South and 44²1'32'" West at the average altitude of $277 \mathrm{~m}$. According to the classification of Köppen, the climate of the region falls into the type Aw, considered a tropical zone with dry winter (Alvares, Stapez, Sentelhas, Gonçalves, \& Sparovek, 2013).

We used 2,160 broilers from three breeding flocks (Ross 308, Cobb 500 and Hubbard Flex) equally divided between males and females. The chicks were at 42,37 and 38 weeks of age. The hatching eggs were purchased from breeder farms located in the states of Ceará, Minas Gerais, and Goiás, and transported in properly equipped trucks to Teresina, PI for incubation. The eggs were incubated in the hatchery with a capacity of 5400 eggs.

Upon hatching, one-day old birds were weighed and distributed using a completely randomized experimental design with a factorial arrangement (3 strains and 2 sexes) and six replicates of 60 birds each, at a stocking density of $30 \mathrm{birds} / \mathrm{m} 2$. The initial mean weights $( \pm \mathrm{s})$ were: $40.4 \pm 0.03 ; 41.4 \pm$ 0.10 ; and $42.2 \pm 0.12 \mathrm{~g}$ for the males of the Cobb, Ross, and Hubbard strains, and $40.4 \pm 0.05 ; 39.7 \pm$ 0.13 ; and $41.3 \pm 0.14 \mathrm{~g}$ for the females, respectively.
Each pen was fitted with a bell water drinker and a one-cylinder feeder and placed in a masonry shed with ceramic tile roof and cement floor, which was covered with rice straw (10 cm thickness). The dividers between the boxes were made of flat wire mesh, and curtains were used to control the temperature. The light program during the experimental period was $23 \mathrm{hr}$ (natural + artificial light) until the seventh day, $20 \mathrm{hr}$ (natural + artificial light) from the eighth to the $42 \mathrm{nd}$ day, increased to $22 \mathrm{hr}$ (natural + artificial light) afterwards.

Environmental temperature and relative humidity, maximum and minimum, were recorded daily by a thermo-hygrometer located in the geometric center of the shed.

\section{Diets and feeding program}

The diet was based on corn and soybean meal formulated to provide nutritional requirements for male broilers of superior quality according to the recommendations of the Brazilian Poultry and Pork Tables (Rostagno et al., 2011). It consisted of four regimens according to the age of the birds: 1 to 7 days, 8 to 21 days, 22 to 42 days, and 43 to 56 days. The animals had free access to water and feed throughout the experimental period.

\section{Measurements}

The sample birds with a weight close to the average weight of each pen $( \pm 5 \%)$ were slaughtered and weighed every week (from 1 to 56 days old). At 1, 7 and 14 days of age, five birds per pen were selected, then three birds per pen were selected at $21,28,35,42,49$, and 56 days, so a total of 1188 birds were processed over the trial period.

The selected birds were separated and kept without food for 24 hours to clean the digestive tract (water was provided). The birds were weighed to obtain fasting weight, slaughtered by cervical dislocation, de-feathered, eviscerated, and dissected to measure the weight of breasts, thighs, and drumsticks. 
Analyses of body growth

We used fitted Gompertz equation to analyze each strain and sex, the fasted body weight (FW), breast weight (BW), thigh weight (TW) and drumstick weight (DW).

The growth curves were obtained using the Gompertz model (1825) as follows:

$$
\mathrm{W}_{\mathrm{t}}=\mathrm{Wm} \cdot \exp \left(-\exp \left(-\mathrm{b} \cdot\left(\mathrm{t}-\mathrm{t}^{*}\right)\right)\right) \text {; }
$$

In this equation Wt (grams), the weight of the bird at time $t$, is expressed using the mature weight of the animal Wm (grams), rate of the maturing (b); and the time when the growth rate is at its maximum $t^{*}$ (days).

To verify the strain effect on the Gompertz curve parameters (Wm, b, and $\left.t^{*}\right)$, we checked the equality of parameters and the identity of non-linear models (Regazzi, 2003), testing the following hypotheses for males and females separately:

$1-\mathrm{H}_{01}: \mathrm{Wm}_{\text {Cobb }}=\mathrm{Wm}_{\text {Ross }}=\mathrm{Wm}_{\text {Hubbard }}=\mathrm{Wm} v \mathrm{~s}$ $\mathrm{H}_{\mathrm{a} 1}$ : not all $\mathrm{Wm}$ are equal.

2- $\mathrm{H}_{02}: \mathrm{b}_{\text {Cobb }}=\mathrm{b}_{\text {Ross }}=\mathrm{b}_{\text {Hubbard }}=\mathrm{b}$ vs $\mathrm{H}_{\mathrm{a} 2}$ : not all $\mathrm{b}_{\mathrm{i}}$ are equal.

$3-\mathrm{H}_{03}: \mathrm{t}^{*}{ }_{\text {Cobb }}=\mathrm{t}^{*}{ }_{\text {Ross }}=\mathrm{t}^{*}{ }_{\text {Hubbard }}=\mathrm{t}^{*}$ vs $\mathrm{H}_{\mathrm{a} 3}$ : not all $\mathrm{t}^{*}{ }_{\mathrm{i}}$ are equal.

4- $\mathrm{H}_{04}: \mathrm{Wm}_{\text {Cobb }}=\mathrm{Wm}_{\text {Ross }}=\mathrm{Wm}_{\text {Hubbard }}=\mathrm{Wm} \mathrm{e}$ $\mathrm{t}^{*}{ }_{\text {Cobb }}=\mathrm{t}^{*}{ }_{\text {Ross }}=\mathrm{t}^{*}{ }_{\text {Hubbard }}=\mathrm{t}^{*}$ vs $\mathrm{H}_{\mathrm{a} 4}$ : at least an equality is an inequality.

5- $\mathrm{H}_{05}: \mathrm{Wm}_{\text {Cobb }}=\mathrm{Wm}_{\text {Ross }}=\mathrm{Wm}_{\text {Hubbard }}=\mathrm{Wm} \mathrm{e}$ $\mathrm{b}_{\text {Cobb }}=\mathrm{b}_{\text {Ross }}=\mathrm{b}_{\text {Hubbard }}=\mathrm{b} v s \mathrm{H}_{\mathrm{a} 5}$ : at least an equality is an inequality.

6- $\mathrm{H}_{06}: \mathrm{Wm}_{\text {Cobb }}=\mathrm{Wm}_{\text {Ross }}=\mathrm{Wm}_{\text {Hubbard }}=\mathrm{W}_{\mathrm{m}}$ e $\mathrm{b}_{\text {Cobb }}$ $=b_{\text {Ross }}=b_{\text {Hubbard }}=$ b e $t_{\text {Cobb }}^{*}=t^{*}{ }_{\text {Ross }}=t^{*}{ }_{\text {Hubbard }}=\mathrm{t}^{*}$ vs $\mathrm{H}_{\mathrm{a}}$ : at least an equality is an inequality.

To test the different hypotheses, we used the statistics proposed by Regazzi (2003):

$\chi^{2}$ calculated $=-n \cdot \ln \left(\mathrm{RSS}_{\Omega} / \mathrm{RSS} \omega\right)$ where: $\mathrm{n}$ = sample size, $\ln =$ natural logarithm $(\log 2,7183)$, $\mathrm{RSS}_{\Omega}=$ residual sums of squares of the unrestricted model $(\Omega)$, without parametric constraints, where individual parameters are adjusted to the curves of each strain and sex; RSS $\omega=$ residual sums of squares of models with parametric constraints $\left(\omega_{1}\right.$ to $\left.\omega_{6}\right)$ imposed to test the hypotheses $\left(\mathrm{H}_{01}\right.$ to $\left.\mathrm{H}_{06}\right)$. The decision rule is as follows: if $\chi^{2}$ calculated $\geq \chi^{2}$ tabulated, reject $\mathrm{H}_{0}$. Otherwise, $\mathrm{H}_{0}$ is not rejected, $\chi^{2}$ tabulated is determined according to the level of significance of the test $(\alpha=0.05)$ and degrees of freedom using the difference between the number of parameters estimated in the model $\Omega$ and the number of parameters of each model wi. Considering the decision in relation to $\mathrm{H}_{0 \mathrm{i}}(\mathrm{i}=1$ to 6$)$, the estimates of te growth rate (g/day) of the different evaluated characteristics were obtained by means of the derivative of the Gompertz equation, expressed as a function of the weight at time $t: d W / d t=b . W_{t}$. $\ln \left(\mathrm{Wm} / \mathrm{W}_{\mathrm{t}}\right)$; where: $\mathrm{dW} / \mathrm{dt}=$ growth rate $(\mathrm{g} /$ day $)$ of the different evaluated characteristics (g/day).

\section{Statistical analysis}

The adjustments of the individual models for each strain and sex, as well as the unrestricted $(\Omega)$ and restricted $\left(\omega_{1}\right.$ to $\left.\omega_{6}\right)$ models for each sex, were performed using the NLIN procedure of SAS software (Statistical Analysis System, 9.1), using the iterative method of Gauss-Newton.

\section{Results and Discussion}

The values for average, minimum and maximum temperatures, and relative humidity of the air within the shed in the period from day 1 to day 56 were $28.1 \pm 0.6^{\circ} \mathrm{C}, 22.1 \pm 1.2^{\circ} \mathrm{C}, 34.1 \pm 0.9^{\circ} \mathrm{C}$, and $72.3 \pm 14.7 \%$, respectively. The mean and maximum recorded temperatures were above the ideal temperatures (below $26^{\circ} \mathrm{C}$ starting from 18 days of age) recommended by the strains' manuals (Aviagen, 2015; Cobb, 2008; Hubbard, 2016).

For all evaluated characteristics (fasted bird, breast, thigh, and drumstick weight) convergence 
was observed $(\mathrm{P}<0.001)$ using the iterative method of the Gompertz curves were estimated individually of Gauss-Newton, so the parameters (Wm, b, and $t^{*}$ )

for males and females of all strains (Table 1).

Table 1

Estimates of the Gompertz model parameters for the fasted weight, breast weight, thighs weigh and drumsticks weight of broilers of different strains and sexes $(n=198)$

\begin{tabular}{ccccccc}
\hline \multirow{2}{*}{ Strain } & \multicolumn{5}{c}{ Males } \\
\cline { 2 - 6 } & \multicolumn{5}{c}{ Parameter } & \multicolumn{3}{c}{ Females } \\
\cline { 2 - 6 } $\mathrm{Wm}^{1}$ & $\mathrm{~b}^{2}$ & \multicolumn{5}{c}{ Parameter } \\
\hline Cobb & $4915.1 \pm 373.5$ & $0.036 \pm 0.002$ & $41.4 \pm 2.3$ & $3659.1 \pm 190.1$ & $0.041 \pm 0.002$ & $35.5 \pm 1.4$ \\
Ross & $5909.8 \pm 494.9$ & $0.033 \pm 0.002$ & $45.2 \pm 2.6$ & $4636.6 \pm 328.2$ & $0.035 \pm 0.002$ & $41.9 \pm 2.2$ \\
Hubbard & $5275.6 \pm 364.9$ & $0.037 \pm 0.002$ & $41.2 \pm 2.0$ & $4306.1 \pm 235.9$ & $0.039 \pm 0.002$ & $38.3 \pm 1.5$ \\
\hline \multicolumn{5}{c}{ Breast Weight (BW) } \\
\hline Cobb & $1765.3 \pm 296.7$ & $0.032 \pm 0.003$ & $50.1 \pm 5.1$ & $1132.5 \pm 99.4$ & $0.041 \pm 0.003$ & $40.1 \pm 2.4$ \\
Ross & $1404.8 \pm 156.1$ & $0.038 \pm 0.003$ & $43.5 \pm 3.1$ & $1316.2 \pm 139.9$ & $0.037 \pm 0.003$ & $44.3 \pm 3.0$ \\
Hubbard & $1258.7 \pm 126.3$ & $0.042 \pm 0.004$ & $40.7 \pm 2.6$ & $1236.7 \pm 86.7$ & $0.045 \pm 0.003$ & $39.4 \pm 1.9$ \\
\hline \multicolumn{5}{c}{ Thighs Weight (TW) } \\
\hline Cobb & $727.2 \pm 114.1$ & $0.030 \pm 0.003$ & $52.2 \pm 5.0$ & $432.1 \pm 48.9$ & $0.036 \pm 0.003$ & $42.3 \pm 3.4$ \\
Ross & $579.3 \pm 60.1$ & $0.037 \pm 0.003$ & $43.6 \pm 2.9$ & $345.1 \pm 24.4$ & $0.046 \pm 0.003$ & $34.7 \pm 1.8$ \\
Hubbard & $619.1 \pm 55.9$ & $0.039 \pm 0.003$ & $42.8 \pm 2.5$ & $422.8 \pm 29.6$ & $0.044 \pm 0.003$ & $37.3 \pm 1.8$ \\
\hline \multicolumn{5}{c}{ Drumsticks Weight (DW) } \\
\hline Cobb & $1256.0 \pm 369.8$ & $0.024 \pm 0.004$ & $67.8 \pm 10.4$ & $732.9 \pm 142.0$ & $0.028 \pm 0.003$ & $55.8 \pm 6.6$ \\
Ross & $779.9 \pm 129.4$ & $0.032 \pm 0.004$ & $50.7 \pm 5.1$ & $423.0 \pm 42.0$ & $0.040 \pm 0.004$ & $39.1 \pm 2.7$ \\
Hubbard & $937.2 \pm 160.3$ & $0.030 \pm 0.003$ & $53.8 \pm 5.4$ & $554.2 \pm 57.0$ & $0.037 \pm 0.003$ & $43.2 \pm 2.9$ \\
\hline
\end{tabular}

${ }^{1} \mathrm{Wm}=$ weight at maturity $(\mathrm{g}) ;{ }^{2} \mathrm{~b}=$ rate of maturing (per day); ${ }^{3} \mathrm{t}^{*}=$ time at which growth rate is maximized (days).

Similar to observations of Demuner et al. (2017) with different broiler strains, the females had lower weight at maturity $(\mathrm{Wm})$ and higher values for the maturity rates (b) compared to the males; there differences were revealed earlier than most of the characteristics evaluated. The exception was observed for Ross strain BW, where females tended achieve maximum growth rate later $\left(t^{*}=44.3\right.$ days $)$ than the males ( $t^{*}=43.5$ days)

The effects of sex on the parameters of growth curves of the body and parts of broilers were evaluated by several groups (Demuner et al., 2017; Marcato et al., 2008; Scheuermann, Bilgili, Hess, \& Mulvaney, 2003). Sex plays a role in broiler development, so females tend to be faster in body growth and in most of the carcass characteristics with smaller Wm and higher $b$, reaching the maximum growth rate at lower ages relative to males (Tholon \& Queiroz, 2009) as we observed as well.

Specifics of the growth for male and female broilers allow optimization of management practices when broilers are separated by sex. For example, it is possible to regulate the height of water source and feeders, and to standardize equipment in the slaughter line as per the common practice in the poultry industry.

Accordingly, we compared the effects of the strain on the parameters $\left(\mathrm{Wm}, \mathrm{b}\right.$, and $\left.\mathrm{t}^{*}\right)$ of the 
characteristics evaluated in the present study for each sex, while comparisons of sex within each strain were not performed.

The strains' effects on the parameters of the FW, BW, TW and DW curves were explored by testing the likelihood ratio (-n. $\left.\ln \left(\mathrm{RSS}_{\Omega} / \mathrm{RSS}_{\omega}\right)\right)$, by the chi-square statistic $(\chi 2)$ (Regassi, 2003) to verify the equality of parameters and the identity of nonlinear regression models. Thus, it was possible to verify if the subsets of parameters $\left(\omega_{1}\right.$ to $\left.\omega_{6}\right)$, estimated with restrictions on $\mathrm{H}_{0}\left(\mathrm{H}_{01}\right.$ to $\left.\mathrm{H}_{06}\right)$, differ from the set of parameters without restrictions $(\Omega)$. Considering the FW of the males, the models $\omega_{1}, \omega_{2}$ and $\omega_{3}$, with a restriction imposed on $\mathrm{W}_{\mathrm{m}}\left(\mathrm{H}_{01}\right), \mathrm{b}\left(\mathrm{H}_{02}\right)$ or $\mathrm{t}^{*}\left(\mathrm{H}_{03}\right)$, did not differ $(\mathrm{P}>0.05)$ from the $\Omega$ model with the non-rejection of the $\mathrm{H}_{01}(\mathrm{P}=0.249), \mathrm{H}_{02}(\mathrm{P}=0.387)$, and $\mathrm{H}_{03}(\mathrm{P}=0.375)$ hypotheses. Since the models referring to these hypotheses have the same number of parameters, model $\omega_{2}$ with the smallest residual sums of squares is the best to describe the growth of the FW (Table 2).

\section{Table 2}

Estimates of the values of the parameters of unrestricted $(\Omega)$ and restricted model $\left(\omega_{1}\right.$ to $\left.\omega_{6}\right)$, residuals sums of squares, Chi-square calculated and significance level for the fasted weight of different males broilers strains

\begin{tabular}{|c|c|c|c|c|c|c|c|c|}
\hline \multirow{2}{*}{ Strain } & \multirow{2}{*}{ Parameter } & \multicolumn{7}{|c|}{ Models $^{1}$} \\
\hline & & $\Omega$ & $\omega_{1}$ & $\omega_{2}$ & $\omega_{3}$ & $\omega_{4}$ & $\omega_{5}$ & $\omega_{6}$ \\
\hline \multirow{3}{*}{ Cobb } & $\mathrm{Wm}$ & 4915.1 & - & 4975.1 & 5110.9 & - & - & - \\
\hline & $\mathrm{b}$ & 0.036 & 0.033 & - & 0.035 & 0.036 & - & - \\
\hline & $t^{*}$ & 41.37 & 44.05 & 41.73 & - & - & 44 & - \\
\hline \multirow{3}{*}{ Ross } & $\mathrm{Wm}$ & 5909.8 & - & 5458.3 & 5411.3 & - & - & - \\
\hline & $\mathrm{b}$ & 0.033 & 0.036 & - & 0.036 & 0.036 & - & - \\
\hline & $t^{*}$ & 45.22 & 42.36 & 42.79 & - & - & 42.88 & - \\
\hline \multirow{3}{*}{ Hubbard } & $\mathrm{Wm}$ & 5275.6 & - & 5607.8 & 5523.1 & - & - & - \\
\hline & $\mathrm{b}$ & 0.037 & 0.037 & - & 0.036 & 0.036 & - & - \\
\hline & $t^{*}$ & 41.21 & 41.73 & 43.00 & - & - & 42.46 & - \\
\hline \multirow{3}{*}{ Common } & $\mathrm{Wm}$ & - & 5372.0 & - & - & 5240.9 & 5450.7 & 5354.2 \\
\hline & $\mathrm{b}$ & - & - & 0.035 & - & - & 0.035 & 0.035 \\
\hline & $t^{*}$ & - & - & - & 42.55 & 41.94 & - & 42.58 \\
\hline \multicolumn{2}{|c|}{$\operatorname{RSS}\left(n \sigma^{2}\right)^{2}$} & 3092823 & 3119154 & 3110777 & 3111391 & 3651436 & 3322388 & 3659791 \\
\hline \multicolumn{2}{|c|}{$\chi^{2}$ calculated $^{3}$} & & 2.781 & 1.899 & 1.963 & 54.460 & 23.485 & 55.120 \\
\hline \multicolumn{2}{|c|}{$\chi^{2}$ tabulated $^{4}$} & & 5.991 & 5.991 & 5.991 & 9.488 & 9.488 & 12.593 \\
\hline \multicolumn{2}{|c|}{$P\left(\chi^{2} \text { tab }>\chi^{2} \mathrm{calc}\right)^{5}$} & & 0.249 & 0.387 & 0.375 & $<0.001$ & $<0.001$ & $<0.001$ \\
\hline \multicolumn{2}{|c|}{ Decision in relation to $\mathrm{H}_{0 \mathrm{i}}$} & & No Reject & No Reject & No Reject & Reject & Reject & Reject \\
\hline
\end{tabular}

Abbreviations: RSS - residuals sums of squares ; $\chi^{2}$ cal - Chi-square calculated; $P$ - significance level

${ }_{1}^{1}$ to $_{6}$ adjusted according hypotheses $\mathrm{H}_{01}$ to $\mathrm{H}_{06}$, respectively; ${ }^{2}$ residuals sums of squares $(\mathrm{n}=328) ;{ }^{3} \chi^{2}$ calculated $=-n$.ln $\left(\mathrm{RSS}_{\Omega} /\right.$

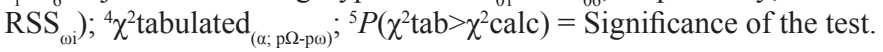

It was observed that the FW growth curves of the Cobb, Ross and Hubbard male broilers had the common parameter $\mathrm{b}(\mathrm{b}=0.035 \mathrm{~g} / \mathrm{day} / \mathrm{g})$, while the parameters $\mathrm{W}_{\mathrm{m}}$ and $\mathrm{t}^{*}$ were different. The males of the Hubbard strain presented higher weight at maturity $\left(\mathrm{W}_{\mathrm{m}}=5607.8 \mathrm{~g}\right)$, followed by the Ross $\left(\mathrm{W}_{\mathrm{m}}=5458.3 \mathrm{~g}\right)$ and the Cobb $\left(\mathrm{W}_{\mathrm{m}}=4975.1 \mathrm{~g}\right)$; they also had the maximum growth rate at a higher 
age $\left(\mathrm{t}^{*}=43.0\right.$ days $)$ compared to the Ross $(\mathrm{t} *=42.8$ days) and the Cobb ( $\mathrm{t}^{*}=41.7$ days $)$ strains.

When the parameter $b$ is similar and the $\mathrm{W}_{\mathrm{m}}$ is different, an important practical consideration is faster growth for the strain with the highest $\mathrm{W}_{\mathrm{m}}$, with higher growth rates ( $\mathrm{g} /$ day) for a given body weight
(Hancock et al., 1995). The results of the present study confirmed this conclusion, with the growth rate (g/day) of different strains directly proportional to their $\mathrm{W}_{\mathrm{m}}$, and the highest growth rate ( $\mathrm{g} /$ day) for the Hubbard strain followed by the Ross and then the Cobb with the lowest rate (Table 3).

Table 3

Estimates of fasted weight and growth rates of different males broilers strains according to age

\begin{tabular}{ccccccc}
\hline \multirow{2}{*}{ Age } & \multicolumn{9}{c}{ Strain } \\
\cline { 2 - 7 } & \multicolumn{2}{c}{ Cobb } & \multicolumn{2}{c}{ Ross } & \multicolumn{2}{c}{ Hubbard } \\
\cline { 2 - 7 } & $\mathrm{FW}^{1}(\mathrm{~g})$ & $\mathrm{GR}^{4}(\mathrm{~g} /$ day $)$ & $\mathrm{FW}^{2}(\mathrm{~g})$ & $\mathrm{GR}(\mathrm{g} /$ day $)$ & $\mathrm{FW}^{3}(\mathrm{~g})$ & $\mathrm{GR}(\mathrm{g} /$ day $)$ \\
\hline 1 & 66.95 & 10.09 & 62.45 & 9.77 & 62.04 & 9.78 \\
7 & 170.72 & 20.15 & 164.89 & 20.20 & 165.09 & 20.37 \\
14 & 355.24 & 32.81 & 352.74 & 33.81 & 355.15 & 34.30 \\
21 & 630.39 & 45.58 & 639.66 & 48.00 & 646.87 & 48.90 \\
28 & 987.56 & 55.89 & 1019.24 & 59.86 & 1034.27 & 61.19 \\
35 & 1403.32 & 62.16 & 1467.70 & 67.47 & 1493.36 & 69.16 \\
42 & 1847.53 & 64.06 & 1952.48 & 70.25 & 1990.80 & 72.16 \\
49 & 2291.26 & 62.18 & 2441.20 & 68.75 & 2493.22 & 70.73 \\
56 & 2711.71 & 57.60 & 2907.62 & 64.09 & 2973.41 & 66.03 \\
\hline
\end{tabular}

Abbreviations: FW - fasted weight; GR - growth rates

${ }^{1} \mathrm{FWt}=4975.1 \cdot \exp (-\exp (-0.035 .($ Age $-41,73))) ;{ }^{2} \mathrm{FWt}=5458.3 \cdot \exp (-\exp (-0.035 \cdot($ Age -42.79$))) ;{ }^{3} \mathrm{FW}_{\mathrm{t}}=5607.8$. $\exp (-\exp (-0.035 .(\mathrm{Age}-$ 43.00))); ${ }^{4}$ Calculated by the derivatives of the Gompertz equations.

For the BW of the males, we observed that all subsets of parameters $\left(\omega_{1}\right.$ to $\left.\omega_{6}\right)$ were similar to the estimated set without restrictions $(\Omega)$, since none of the hypotheses $\left(\mathrm{H}_{01}\right.$ to $\left.\mathrm{H}_{06}\right)$ was rejected $(\mathrm{P}>0.05)$.
Applying the "Parsimony Principle", the $\omega_{6}$ model was the most appropriate to describe BW growth, because it had the lowest number of parameters (Table 4).

Table 4

Estimates of the values of the parameters of unrestricted $(\Omega)$ and restricted model $\left(\omega_{1}\right.$ to $\left.\omega_{6}\right)$, residuals sums of squares, Chi-square calculated and significance level for the breast weight of different males broilers strains

\begin{tabular}{|c|c|c|c|c|c|c|c|c|}
\hline \multirow{2}{*}{ Strain } & \multirow{2}{*}{ Parameter } & \multicolumn{7}{|c|}{ Models $^{1}$} \\
\hline & & $\Omega$ & $\omega_{1}$ & $\omega_{2}$ & $\omega_{3}$ & $\omega_{4}$ & $\omega_{5}$ & $\omega_{6}$ \\
\hline \multirow{3}{*}{ Cobb } & $\mathrm{Wm}$ & 1765.3 & - & 1425.6 & 1422.7 & - & - & - \\
\hline & $\mathrm{b}$ & 0.032 & 0.037 & - & 0.037 & 0.037 & - & - \\
\hline & $\mathrm{t}^{*}$ & 50.14 & 43.94 & 43.94 & - & - & 43.96 & - \\
\hline \multirow{3}{*}{ Ross } & $\mathrm{Wm}$ & 1404.8 & - & 1429.4 & 1426.7 & - & - & - \\
\hline & $\mathrm{b}$ & 0.038 & 0.038 & - & 0.038 & 0.038 & - & - \\
\hline & $\mathrm{t}^{*}$ & 43.47 & 43.82 & 43.95 & - & - & 43.92 & - \\
\hline
\end{tabular}


continuation

\begin{tabular}{|c|c|c|c|c|c|c|c|c|}
\hline \multirow{3}{*}{ Hubbard } & $\mathrm{Wm}$ & 1258.7 & - & 1424.7 & 1419.5 & - & - & - \\
\hline & $\mathrm{b}$ & 0.042 & 0.038 & - & 0.038 & 0.038 & - & - \\
\hline & $t^{*}$ & 40.65 & 43.93 & 44.02 & - & - & 44.06 & - \\
\hline \multirow{3}{*}{ Common } & $\mathrm{Wm}$ & - & 1422.7 & - & - & 1424.6 & 1427.1 & 1427.0 \\
\hline & $\mathrm{b}$ & - & - & 0.038 & - & - & 0.037 & 0.037 \\
\hline & $t^{*}$ & - & - & - & 43.90 & 43.93 & - & 43.97 \\
\hline \multicolumn{2}{|c|}{$\operatorname{RSS}\left(n \sigma^{2}\right)^{2}$} & 441911 & 446650 & 446924 & 446633 & 446788 & 446935 & 447137 \\
\hline \multicolumn{2}{|c|}{$\chi^{2}$ calculated $^{3}$} & & 3.403 & 3.598 & 3.391 & 3.501 & 3.606 & 3.750 \\
\hline \multicolumn{2}{|c|}{$\chi^{2}$ tabulated $^{4}$} & & 5.991 & 5.991 & 5.991 & 9.488 & 9.488 & 12.593 \\
\hline \multicolumn{2}{|c|}{$P\left(\chi^{2} \mathrm{tab}>\chi^{2} \mathrm{calc}\right)^{5}$} & & 0.182 & 0.165 & 0.183 & 0.477 & 0.462 & 0.710 \\
\hline \multicolumn{2}{|c|}{ Decision in relation to $\mathrm{H}_{0 \mathrm{i}}$} & & No Reject & No Reject & No Reject & No Reject & No Reject & No Reject \\
\hline
\end{tabular}

Abbreviations: RSS - residuals sums of squares ; $\chi^{2}$ cal - Chi-square calculated; $P$ - significance level

${ }_{1}^{1}$ to ${ }_{6}$ adjusted according hypotheses $\mathrm{H}_{01}$ to $\mathrm{H}_{06}$, respectively; ${ }^{2}$ residuals sums of squares $(\mathrm{n}=319) ;{ }^{3} \chi^{2}$ calculated $=-\mathrm{n} . \mathrm{ln}\left(\mathrm{RSS} \mathrm{S}_{\Omega}\right.$

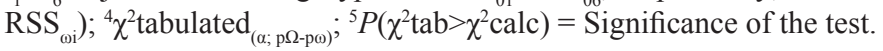

This result demonstrates that the pattern of breast growth is similar for the Cobb, Ross and Hubbard males, requiring only a curve to describe the BW as a function of age, and the parameters $\mathrm{W}_{\mathrm{m}}(1427 \mathrm{~g}), \mathrm{b}$ $(0.037 \mathrm{~g} / \mathrm{day} / \mathrm{g})$ and $\mathrm{t}^{*}$ (43.97 days) common among strains. As in FW, BW reached the highest growth rate (g/day) between 42 and 45 days, corresponding to the age range usually used for the slaughter of broilers in the Brazilian poultry industry (Table 5).

Table 5

Estimates of breast weight and growth rates of males Cobb, Ross and Hubbard broilers according to age

\begin{tabular}{ccc}
\hline Age & $\mathrm{BW}^{1}(\mathrm{~g})$ & $\mathrm{GR}^{2}(\mathrm{~g} /$ day $)$ \\
\hline 1 & 8.80 & 1.66 \\
7 & 28.11 & 4.08 \\
14 & 68.88 & 7.73 \\
21 & 137.54 & 11.90 \\
28 & 234.57 & 15.67 \\
35 & 354.15 & 18.26 \\
42 & 486.73 & 19.37 \\
49 & 622.13 & 19.11 \\
56 & 751.88 & 17.83 \\
\hline
\end{tabular}

Abbreviations: BW - breast weight; GR - growth rates

${ }^{1} \mathrm{BWt}=1427 . \exp \left(-\exp (-0.037 .(\right.$ Age-43.97) $)) ;{ }^{2}$ Calculated by the derivatives of the Gompertz equation.

Based on the results presented in Tables 3 and 5, the $\mathrm{BW}$ is $26.3 \%, 24.9 \%$, and $24.4 \%$ of the $\mathrm{FW}$ in the Cobb, Ross and Hubbard strains, respectively if birds are slaughtered at 42 days of age. This conclusion suggests that at the time of slaughter the yield of the breast is differentiated, which is important considering the high economic value of this cut. As we observed for FW, the models $\omega_{1}, \omega_{2}$ and $\omega_{3}$ for TW were similar $(\mathrm{P}>0.05)$ to the model $\Omega$, with the model $\omega_{1}$ presenting the smallest residual sums of squares $(\mathrm{RSS}=64039.7)$; this model was considered the best to describe the growth of TW (Table 6). 
Table 6

Estimates of the values of the parameters of unrestricted $(\Omega)$ and restricted model $\left(\omega_{1}\right.$ to $\left.\omega_{6}\right)$, residuals sums of squares, Chi-square calculated and significance level for the thighs weight of different males broilers strains

\begin{tabular}{|c|c|c|c|c|c|c|c|c|}
\hline \multirow{2}{*}{ Strain } & \multirow{2}{*}{ Parameter } & \multicolumn{7}{|c|}{ Models $^{1}$} \\
\hline & & $\Omega$ & $\omega_{1}$ & $\omega_{2}$ & $\omega_{3}$ & $\omega_{4}$ & $\omega_{5}$ & $\omega_{6}$ \\
\hline \multirow{3}{*}{ Cobb } & $\mathrm{Wm}$ & 727.2 & - & 576.8 & 576.8 & - & - & - \\
\hline & $\mathrm{b}$ & 0.030 & 0.033 & - & 0.036 & 0.0276 & - & - \\
\hline & $t^{*}$ & 52.16 & 47.63 & 45.15 & - & - & 48.56 & - \\
\hline \multirow{3}{*}{ Ross } & $\mathrm{Wm}$ & 579.3 & - & 606.6 & 612.8 & - & - & - \\
\hline & $\mathrm{b}$ & 0.037 & 0.035 & - & 0.036 & 0.0264 & - & - \\
\hline & $t^{*}$ & 43.55 & 45.79 & 44.88 & - & - & 47.13 & - \\
\hline \multirow{3}{*}{ Hubbard } & $\mathrm{Wm}$ & 619.1 & - & 682.2 & 673.7 & - & - & - \\
\hline & $\mathrm{b}$ & 0.039 & 0.038 & - & 0.036 & 0.025 & - & - \\
\hline & $\mathrm{t}^{*}$ & 42.79 & 43.10 & 45.55 & - & - & 45.1 & - \\
\hline \multirow{3}{*}{ Common } & $\mathrm{Wm}$ & - & 629.2 & - & - & 1005.8 & 659.5 & 628.0 \\
\hline & B & - & - & 0.036 & - & - & 0.034 & 0.035 \\
\hline & $\mathrm{t}^{*}$ & - & - & - & 45.17 & 60.54 & - & 45.55 \\
\hline \multicolumn{2}{|c|}{$\operatorname{RSS}\left(n \sigma^{2}\right)^{2}$} & 63726.9 & 64039.7 & 64582.3 & 64509.9 & 86957.4 & 69077.4 & 92027 \\
\hline \multicolumn{2}{|c|}{$\chi^{2}$ calculated $^{3}$} & & 1.582 & 4.307 & 3.944 & 100.392 & 26.041 & 118.695 \\
\hline \multicolumn{2}{|c|}{$\chi^{2}$ tabulated $^{4}$} & & 5.991 & 5.991 & 5.991 & 9.488 & 9.488 & 12.593 \\
\hline \multicolumn{2}{|c|}{$P\left(\chi^{2} \mathrm{tab}>\chi^{2} \mathrm{calc}\right)^{5}$} & & 0.453 & 0.116 & 0.139 & $<0.001$ & $<0.001$ & $<0.001$ \\
\hline \multicolumn{2}{|c|}{ Decision in relation to $\mathrm{H}_{0 \mathrm{i}}$} & & No Reject & No Reject & No Reject & Reject & Reject & Reject \\
\hline
\end{tabular}

Abbreviations: RSS - residuals sums of squares ; $\chi^{2}$ cal - Chi-square calculated; $P$ - significance level

${ }_{1}^{1}$ to ${ }_{6}$ adjusted according hypotheses $\mathrm{H}_{01}$ to $\mathrm{H}_{06}$, respectively; ${ }^{2}$ residuals sums of squares $(\mathrm{n}=323) ;{ }^{3} \chi^{2}$ calculated $=-\mathrm{n}$.ln $\left(\mathrm{RSS}_{\Omega} /\right.$

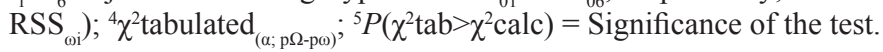

The growth curves of the TW in the Cobb, Ross and Hubbard strains had the common $\mathrm{W}_{\mathrm{m}}$ parameter $\left(\mathrm{W}_{\mathrm{m}}=629.2 \mathrm{~g}\right)$, which had different parameters $\mathrm{b}$ and $t^{*}$. The males of the Hubbard strain presented higher $\mathrm{b}(\mathrm{b}=0.038 \mathrm{~g} /$ day $/ \mathrm{g})$, followed by the Ross $(\mathrm{b}$
$=0.035 \mathrm{~g} / \mathrm{day} / \mathrm{g})$ and the Cobb $(\mathrm{b}=0.033 \mathrm{~g} / \mathrm{day} / \mathrm{g})$, and reaching the maximum growth rate at a lower age $\left(t^{*}=43.10\right.$ days $)$ compared to the Ross $\left(t^{*}=\right.$ 45.79 days) and the Cobb ( $t^{*}=47.63$ days), so the Hubbard strain grew the fastest (g/day) (Table 7). 
Table 7

Estimates of thighs weight and growth rates of different males broilers strains according to age

\begin{tabular}{ccccccc}
\hline \multirow{2}{*}{ Age } & \multicolumn{6}{c}{ Strain } \\
\cline { 2 - 7 } & \multicolumn{2}{c}{ Cobb } & \multicolumn{2}{c}{ Ross } & \multicolumn{2}{c}{ Hubbard } \\
\cline { 2 - 7 } & $\mathrm{TW}^{1}(\mathrm{~g})$ & $\mathrm{GR}^{4}(\mathrm{~g} /$ day $)$ & $\mathrm{TW}^{2}(\mathrm{~g})$ & $\mathrm{GR}(\mathrm{g} /$ day $)$ & $\mathrm{TW}^{3}(\mathrm{~g})$ & $\mathrm{GR}(\mathrm{g} /$ day $)$ \\
\hline 1 & 5.10 & 0.88 & 4.39 & 0.76 & 3.67 & 0.72 \\
7 & 13.77 & 1.89 & 12.90 & 1.76 & 12.21 & 1.83 \\
14 & 30.29 & 3.31 & 30.03 & 3.20 & 30.66 & 3.52 \\
21 & 56.63 & 4.91 & 58.16 & 4.85 & 62.09 & 5.46 \\
28 & 93.05 & 6.40 & 97.57 & 6.37 & 106.64 & 7.19 \\
35 & 138.02 & 7.54 & 146.29 & 7.47 & 161.42 & 8.34 \\
42 & 188.72 & 8.18 & 200.86 & 8.03 & 221.80 & 8.79 \\
49 & 241.93 & 8.32 & 257.42 & 8.05 & 282.96 & 8.59 \\
56 & 294.65 & 8.05 & 312.60 & 7.65 & 341.02 & 7.94 \\
\hline
\end{tabular}

Abbreviations: TW - thighs weight; GR - growth rates ${ }^{1} \mathrm{TW}=629.2 \cdot \exp \left(-\exp (-0.033 .(\right.$ Age-47.63) $)) ;{ }^{2} \mathrm{TW}=629.2 \cdot \exp (-\exp (-0.035$. $($ Age-45.79) $)) ;{ }^{3} \mathrm{TW}_{\mathrm{t}}=629.2 \cdot \exp \left(-\exp (-0.038 .(\right.$ Age-43.10) $)) ;{ }^{4}$ Calculated by the derivatives of the Gompertz equations.

Contrary to the observed $\mathrm{BW}$, once the three strains reached the maximum growth rate (g/day) at a similar age $\left(\mathrm{t}^{*}=44\right.$ days $)$, the TW for the Hubbard males was higher than for the Ross ( $t^{*}=45,8$ days) and the Cobb strains ( $t^{*}=47,6$ days). At 42 days of age, TW (Table 7 ) was $10.2 \%, 10.3 \%$, and $11.1 \%$ of the FW (Table 3) for the Cobb, Ross and Hubbard males, respectively. The models $\omega_{1}, \omega_{2}$ and $\omega_{3}$ did not differ $(\mathrm{P}>0.05)$ from the $\Omega$ model for $\mathrm{DW}$, so the model $\omega_{1}$ with the smallest residual sums of squares was the best to describe the DW (Table 8).

\section{Table 8}

Estimates of the values of the parameters of unrestricted $(\Omega)$ and restricted model $\left(\omega_{1}\right.$ to $\left.\omega_{6}\right)$, residuals sums of squares, Chi-square calculated and significance level for the drumsticks weight of different males broilers strains

\begin{tabular}{|c|c|c|c|c|c|c|c|c|}
\hline \multirow{2}{*}{ Strain } & \multirow{2}{*}{ Parameter } & \multicolumn{7}{|c|}{ Models $^{1}$} \\
\hline & & $\Omega$ & $\omega_{1}$ & $\omega_{2}$ & $\omega_{3}$ & $\omega_{4}$ & $\omega_{5}$ & $\omega_{6}$ \\
\hline \multirow{3}{*}{ Cobb } & $\mathrm{Wm}$ & 1256.0 & - & 901.6 & 885.5 & - & - & - \\
\hline & $\mathrm{b}$ & 0.024 & 0.028 & - & 0.029 & 0.025 & - & - \\
\hline & $\mathrm{t}^{*}$ & 67.83 & 57.99 & 56.57 & - & - & 58.57 & - \\
\hline \multirow{3}{*}{ Ross } & $\mathrm{Wm}$ & 779.9 & - & 902.4 & 923.4 & - & - & - \\
\hline & $\mathrm{b}$ & 0.032 & 0.028 & - & 0.029 & 0.024 & - & - \\
\hline & $\mathrm{t}^{*}$ & 50.69 & 56.58 & 55.34 & - & - & 57.33 & - \\
\hline \multirow{3}{*}{ Hubbard } & $\mathrm{Wm}$ & 937.2 & - & 1007.9 & 1006.7 & - & - & - \\
\hline & $\mathrm{b}$ & 0.030 & 0.030 & - & 0.029 & 0.023 & - & - \\
\hline & $\mathrm{t}^{*}$ & 53.78 & 53.85 & 56.11 & - & - & 55.62 & - \\
\hline \multirow{3}{*}{ Common } & $\mathrm{Wm}$ & - & 939.4 & - & - & 1362.9 & 972.2 & 947.5 \\
\hline & $\mathrm{b}$ & - & - & 0.029 & - & - & 0,029 & 0.029 \\
\hline & $\mathrm{t}^{*}$ & - & - & - & 56.05 & 68.71 & - & 56.42 \\
\hline
\end{tabular}


continuation

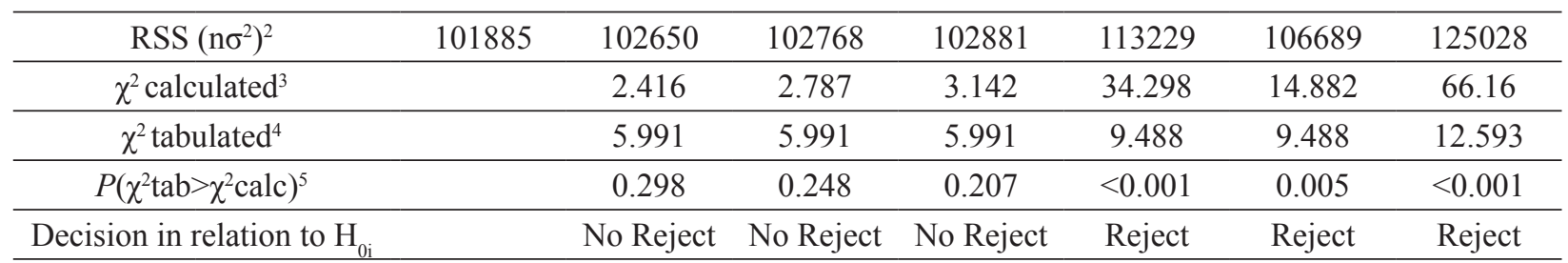

Abbreviations: RSS - residuals sums of squares ; $\chi^{2}$ cal - Chi-square calculated; $P$ - significance level

${ }_{1}^{1}$ to $_{6}$ adjusted according hypotheses $\mathrm{H}_{01}$ to $\mathrm{H}_{06}$, respectively; ${ }^{2}$ residuals sums of squares $(\mathrm{n}=323) ;{ }^{3} \chi^{2}$ calculated $=-\mathrm{n}$. $\ln \left(\mathrm{RSS}_{\Omega} /\right.$

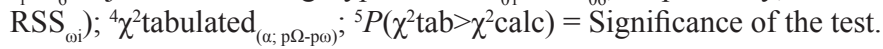

The DW growth curves of male broilers had common $\mathrm{W}_{\mathrm{m}}(939.4 \mathrm{~g})$ with different $\mathrm{b}$ and $\mathrm{t}^{*}$. The Hubbard males has the highest b (0.030 g/day/g), followed by the Ross and the Cobb that had the same parameter $\mathrm{b}(\mathrm{b}=0.028 \mathrm{~g} / \mathrm{day} / \mathrm{g})$. Thus, Hubbard birds were more mature ( $\mathrm{t}^{*}=53.85$ days) than the Ross $\left(t^{*}=56.58\right.$ days $)$ and the Cobb $\left(t^{*}=57.99\right.$ days) birds, with higher growth rates (g/day) of the DW over time (Table 9).

Table 9

Estimates of drumsticks weight and growth rates of different males broilers strains according to age

\begin{tabular}{ccccccc}
\hline \multirow{2}{*}{ Age } & \multicolumn{9}{c}{ Strain } \\
\cline { 2 - 7 } & \multicolumn{2}{c}{ Cobb } & \multicolumn{2}{c}{ Ross } & \multicolumn{2}{c}{ Hubbard } \\
\cline { 2 - 7 } & $\mathrm{DW}^{1}(\mathrm{~g})$ & $\mathrm{GR}^{4}(\mathrm{~g} /$ day $)$ & $\mathrm{DW}^{2}(\mathrm{~g})$ & $\mathrm{GR}(\mathrm{g} /$ day $)$ & $\mathrm{DW}^{3}(\mathrm{~g})$ & $\mathrm{GR}(\mathrm{g} /$ day $)$ \\
\hline 1 & 6.68 & 0.93 & 7.17 & 0.98 & 6.14 & 0.93 \\
7 & 16.12 & 1.83 & 17.07 & 1.92 & 15.92 & 1.95 \\
14 & 33.23 & 3.11 & 34.84 & 3.21 & 34.47 & 3.42 \\
21 & 60.23 & 4.63 & 62.62 & 4.75 & 64.46 & 5.18 \\
28 & 98.21 & 6.21 & 101.41 & 6.32 & 107.08 & 6.98 \\
35 & 146.80 & 7.63 & 150.71 & 7.72 & 161.57 & 8.53 \\
42 & 204.27 & 8.73 & 208.74 & 8.79 & 225.51 & 9.65 \\
49 & 268.01 & 9.41 & 272.82 & 9.45 & 295.49 & 10.25 \\
56 & 335.04 & 9.67 & 339.97 & 9.68 & 367.86 & 10.35 \\
\hline
\end{tabular}

Abbreviations: DW - drumsticks weight; GR - growth rates

${ }^{1} \mathrm{DW}_{\mathrm{t}}=939.4 \cdot \exp \left(-\exp (-0.028 .(\right.$ Age-57.99) $)) ;{ }^{2} \mathrm{DW}_{\mathrm{t}}=939.4 \cdot \exp \left(-\exp (-0.028 .(\right.$ Age-56.58) $)){ }^{3}{ }^{3} \mathrm{DW}_{\mathrm{t}}=939.4 \cdot \exp (-\exp (-0.030 .($ Age$53.85))) ;{ }^{4}$ Calculated by the derivatives of the Gompertz equations.

Although the DW growth pattern was different, our results (Tables 4 and 10) indicated that the relative weight of the drumsticks was similar at 42 days of age at $11.6 \%, 11.1$, and $11.3 \%$ of the FW for the Cobb, Ross and Hubbard strains, respectively.
The strain-dependent effects on the FW were similar in females and males: the $b$ parameter was the same $(\mathrm{b}=0.038 \mathrm{~g} / \mathrm{day} / \mathrm{g})$ and the $\mathrm{Wm}$ and $\mathrm{t}^{*}$ parameters were specific for each strain as supported by the model $\omega_{2}$ with non-rejection of hypothesis $\mathrm{H}_{02}$ (Table 10). 
Table 10

Estimates of the values of the parameters of unrestricted $(\Omega)$ and restricted model $\left(\omega_{1}\right.$ to $\left.\omega_{6}\right)$, residuals sums of squares, Chi-square calculated and significance level for the fasted weight of different females broilers strains

\begin{tabular}{|c|c|c|c|c|c|c|c|c|}
\hline \multirow{2}{*}{ Strain } & \multirow{2}{*}{ Parameter } & \multicolumn{7}{|c|}{ Models $^{1}$} \\
\hline & & $\Omega$ & $\omega_{1}$ & $\omega_{2}$ & $\omega_{3}$ & $\omega_{4}$ & $\omega_{5}$ & $\omega_{6}$ \\
\hline \multirow{3}{*}{ Cobb } & $\mathrm{Wm}$ & 3659.1 & - & 3900.4 & 4041.1 & - & - & - \\
\hline & $\mathrm{b}$ & 0.041 & 0.036 & - & 0.037 & 0.039 & - & - \\
\hline & $t^{*}$ & 35.52 & 39.3 & 37.34 & - & - & 39.32 & - \\
\hline \multirow{3}{*}{ Ross } & $\mathrm{Wm}$ & 4636.6 & - & 4119.5 & 4111.5 & - & - & - \\
\hline & $\mathrm{b}$ & 0.035 & 0.038 & - & 0.038 & 0.040 & - & - \\
\hline & $t^{*}$ & 41.97 & 38.86 & 38.44 & - & - & 39.12 & - \\
\hline \multirow{3}{*}{ Hubbard } & $\mathrm{Wm}$ & 4306.1 & - & 4437.4 & 4320.4 & - & - & - \\
\hline & $\mathrm{b}$ & 0.039 & 0.041 & - & 0.039 & 0.042 & - & - \\
\hline & $t^{*}$ & 38.29 & 37.43 & 39.15 & - & - & 38.03 & - \\
\hline \multirow{3}{*}{ Common } & $\mathrm{Wm}$ & - & 4174.5 & - & - & 3977.3 & 4222 & 4163 \\
\hline & $\mathrm{b}$ & - & - & 0.038 & - & - & 0.038 & 0.038 \\
\hline & $t^{*}$ & - & - & - & 38.38 & 37.12 & - & 38.42 \\
\hline \multicolumn{2}{|c|}{$\operatorname{RSS}\left(\mathrm{n} \sigma^{2}\right)^{2}$} & 1827032 & 1876309 & 1858676 & 1866803 & 2181506 & 2078512 & 2260090 \\
\hline \multicolumn{2}{|c|}{$\chi^{2}$ calculated $^{3}$} & & 8.170 & 5.272 & 6.611 & 54.438 & 39.591 & 65.303 \\
\hline \multicolumn{2}{|c|}{$\chi^{2}$ tabulated $^{4}$} & & 5.991 & 5.991 & 5.991 & 9.488 & 9.488 & 12.593 \\
\hline \multicolumn{2}{|c|}{$P\left(\chi^{2} \text { tab }>\chi^{2} \text { calc }\right)^{5}$} & & 0.016 & 0.071 & 0.036 & $<0.001$ & $<0.001$ & $<0.001$ \\
\hline \multicolumn{2}{|c|}{ Decision in relation to $\mathrm{H}_{0 \mathrm{i}}$} & & Reject & No Reject & Reject & Reject & Reject & Reject \\
\hline
\end{tabular}

Abbreviations: RSS - residuals sums of squares $; \chi^{2}$ cal - Chi-square calculated; $P$ - significance level

${ }_{1}^{1}$ to ${ }_{6}$ adjusted according hypotheses $\mathrm{H}_{01}$ to $\mathrm{H}_{06}$, respectively; ${ }^{2}$ residuals sums of squares $(\mathrm{n}=307) ;{ }^{3} \chi^{2}$ calculated $=-\mathrm{n} . \mathrm{ln}\left(\mathrm{RSS} \mathrm{S}_{\Omega}\right.$ $\left.\operatorname{RSS}_{\omega \mathrm{i}}\right) ; \chi^{2}$ tabulated $(\alpha ; \mathrm{p} \Omega-\mathrm{p} \omega) ;{ }^{5} P\left(\chi^{2} \mathrm{tab}>\chi^{2} \mathrm{calc}\right)=$ Significance of the test.

Similar to males, the females of the Hubbard strain had the highest $\mathrm{W}_{\mathrm{m}}$ (4437.4 g), followed by the Ross $\left(\mathrm{W}_{\mathrm{m}}=4199.5 \mathrm{~g}\right)$ and the Cobb $\left(\mathrm{W}_{\mathrm{m}}=\right.$ $3900.4 \mathrm{~g}$ ), while reaching the highest growth rate later $\left(\mathrm{t}^{*}=39.15\right.$ days) than females of the Ross $\left(\mathrm{t}^{*}=\right.$ 38.44 days) and the Cobb strains $\left(t^{*}=37.34\right.$ days $)$.
Growth rates (g/day) of females were also directly proportional to the Wm, so the Hubbard females had higher growth rates than the Ross or Cobb females (Table 11); this observation agreed with results of Demuner et al. (2017). 
Table 11

Estimates of fasted weight and growth rates of different females broiler strains according to age

\begin{tabular}{ccccccc}
\hline \multirow{2}{*}{ Age } & \multicolumn{5}{c}{ Strain } \\
\cline { 2 - 7 } & \multicolumn{2}{c}{ Cobb } & \multicolumn{2}{c}{ Ross } & \multicolumn{2}{c}{ Hubbard } \\
\cline { 2 - 7 } & $\mathrm{FW}^{1}(\mathrm{~g})$ & $\mathrm{GR}^{4}(\mathrm{~g} /$ day $)$ & $\mathrm{FW}^{2}(\mathrm{~g})$ & $\mathrm{GR}(\mathrm{g} /$ day $)$ & $\mathrm{FW}^{3}(\mathrm{~g})$ & $\mathrm{GR}(\mathrm{g} /$ day $)$ \\
\hline 1 & 62.6 & 9.83 & 55.4 & 9.07 & 53.3 & 8.92 \\
7 & 164.3 & 19.77 & 151.5 & 19.02 & 149.1 & 19.23 \\
14 & 344.2 & 31.75 & 327.7 & 31.52 & 329.4 & 32.55 \\
21 & 606.8 & 42.90 & 592.0 & 43.64 & 604.7 & 45.80 \\
28 & 937.1 & 50.78 & 931.3 & 52.62 & 963.2 & 55.91 \\
35 & 1307.5 & 54.30 & 1318.2 & 57.08 & 1376.1 & 61.22 \\
42 & 1687.7 & 53.72 & 1719.9 & 57.09 & 1808.9 & 61.68 \\
49 & 2052.4 & 50.08 & 2109.1 & 53.66 & 2230.7 & 58.30 \\
56 & 2384.5 & 44.59 & 2466.1 & 48.08 & 2619.4 & 52.47 \\
\hline
\end{tabular}

Abbreviations: FW - fasted weight; GR - growth rates

${ }^{1} \mathrm{FW}_{\mathrm{t}}=3900.4 . \exp \left(-\exp (-0.038 .(\right.$ Age-37.34) $)) ;{ }^{2} \mathrm{FW}_{\mathrm{t}}=4119.5 . \exp \left(-\exp (-0.038 .(\right.$ Age-38.44) $)) ;{ }^{3} \mathrm{FW}_{\mathrm{t}}=4437.4 . \exp (-\exp (-0.038 .($ Age39.15)) $;{ }^{4}$ Calculated by the derivatives of the Gompertz equations.

Females are commonly used for the production of broiler grillers, eviscerated whole birds slaughtered between 33 and 35 days of age with an average weight of 1,450 kg (Sandi, Santos, Mieli, \& Martins, 2011). Considering the recommended weight, the use of strains with higher growth rates during the first weeks of life will result in lower age at slaughter, reducing the time in the field and the costs of production. Selection of the appropriate strain based on the knowledge of the growth patterns for the different strains and sexes will ultimately determine profitability for the producers. The models $\omega_{1}, \omega_{2}$ and $\omega_{3}$ were similar $(\mathrm{P}>0.05)$ to the $\Omega$ model for female $\mathrm{BW}$, and the $\omega_{1}$ model had the smallest residual sums of squares (RSS $=279504$ ) and was the best to describe the growth of this cut. Diverging from the males, the growth pattern of the female BW depended on the strain, so while the growth curves for this cut had the same $\mathrm{W}_{\mathrm{m}}(1182.1 \mathrm{~g})$ for all strains, the $\mathrm{b}$ and $\mathrm{t}^{*}$ parameters were specific for the Cobb, Ross, and Hubbard birds (Table 12). 
Table 12

Estimates of the values of the parameters of unrestricted $(\Omega)$ and restricted model $\left(\omega_{1}\right.$ to $\left.\omega_{6}\right)$, residuals sums of squares, Chi-square calculated and significance level for the breast weight of different females broilers strains

\begin{tabular}{|c|c|c|c|c|c|c|c|c|}
\hline \multirow{2}{*}{ Strain } & \multirow{2}{*}{ Parameter } & \multicolumn{7}{|c|}{ Models $^{1}$} \\
\hline & & $\Omega$ & $\omega_{1}$ & $\omega_{2}$ & $\omega_{3}$ & $\omega_{4}$ & $\omega_{5}$ & $\omega_{6}$ \\
\hline \multirow{3}{*}{ Cobb } & $\mathrm{Wm}$ & 1132.5 & - & 1126.1 & 1168.5 & - & - & - \\
\hline & $\mathrm{b}$ & 0.041 & 0.039 & - & 0.039 & 0.041 & - & - \\
\hline & $t^{*}$ & 40.08 & 41.25 & 39.93 & - & - & 41.38 & - \\
\hline \multirow{3}{*}{ Ross } & $\mathrm{Wm}$ & 1316.2 & - & 1165.2 & 1164.0 & - & - & - \\
\hline & $\mathrm{b}$ & 0.037 & 0.040 & - & 0.041 & 0.042 & - & - \\
\hline & $t^{*}$ & 44.34 & 41.38 & 40.97 & - & - & 40.60 & - \\
\hline \multirow{3}{*}{ Hubbard } & $\mathrm{Wm}$ & 1236.7 & - & 1253.2 & 1207.9 & - & - & - \\
\hline & $\mathrm{b}$ & 0.045 & 0.043 & - & 0.042 & 0.044 & - & - \\
\hline & $\mathrm{t}^{*}$ & 39.38 & 40.36 & 41.9 & - & - & 40.83 & - \\
\hline \multirow{3}{*}{ Common } & $\mathrm{Wm}$ & - & 1182.1 & - & - & 1139.9 & 1195.0 & 1189.4 \\
\hline & $\mathrm{b}$ & - & - & 0.041 & - & - & 0.040 & 0.041 \\
\hline & $t^{*}$ & - & - & - & 40.94 & 40.02 & - & 41.14 \\
\hline \multicolumn{2}{|c|}{$\operatorname{RSS}\left(\mathrm{n} \sigma^{2}\right)^{2}$} & 277934 & 279504 & 281045 & 280139 & 288946 & 292092 & 297481 \\
\hline \multicolumn{2}{|c|}{$\chi^{2}$ calculated $^{3}$} & & 1.718 & 3.395 & 2.410 & 11.851 & 15.154 & 20.730 \\
\hline \multicolumn{2}{|c|}{$\chi^{2}$ tabulated $^{4}$} & & 5.991 & 5.991 & 5.991 & 9.488 & 9.488 & 12.593 \\
\hline \multicolumn{2}{|c|}{$P\left(\chi^{2} \mathrm{tab}>\chi^{2} \mathrm{calc}\right)^{5}$} & & 0.423 & 0.183 & 0.299 & $<0.001$ & $<0.001$ & $<0.001$ \\
\hline \multicolumn{2}{|c|}{ Decision in relation to $\mathrm{H}_{0 \mathrm{i}}$} & & No Reject & No Reject & No Reject & Reject & Reject & Reject \\
\hline
\end{tabular}

Abbreviations: RSS - residuals sums of squares ; $\chi^{2}$ cal - Chi-square calculated; $P$ - significance level

${ }_{1}^{1}$ to ${ }_{6}$ adjusted according hypotheses $\mathrm{H}_{01}$ to $\mathrm{H}_{06}$, respectively; ${ }^{2}$ residuals sums of squares $(\mathrm{n}=305) ;{ }^{3} \chi^{2}$ calculated $=-n . \ln \left(\mathrm{RSS}_{\Omega} /\right.$

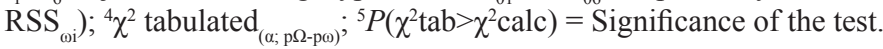

The Hubbard females had the highest $b(0.043$ $\mathrm{g} /$ day $/ \mathrm{g})$, followed by the Ross $(\mathrm{b}=0.040 \mathrm{~g} / \mathrm{day} / \mathrm{g})$ and Cobb ( $b=0.039 \mathrm{~g} / \mathrm{day} / \mathrm{g})$ birds, reaching the maximum growth rate earlier ( $t^{*}=40.36$ days) than the other strains. The differences in the $b$ parameter between the Ross and Cobb strains were less pronounced than with the Hubbard, so that the Ross and Cobb females reached the maximum growth rate at similar ages $(\mathrm{t} *$ Ross $=41,38 \mathrm{vs} \mathrm{t} * \mathrm{Cobb}=$ 41,25 days), approximately a day later than the
Hubbard females. The latter had the highest BW at 42 days $(\mathrm{PP}=465.5 \mathrm{~g})$, while the $\mathrm{BW}$ of the Cobb females ( $\mathrm{PP}=447.6 \mathrm{~g})$ was slightly higher than for the Ross birds ( $\mathrm{PP}=445.7 \mathrm{~g}$ ) (Table 13). Based on the BW:FW ratio at 42 days (Tables 11 and 13) BW represented $26.5 \%, 25.9 \%$, and $25.7 \%$ of the FW for the Cobb, Ross and Hubbard females, respectively; these differences were less pronounced than in the males. 
Table 13

Estimates of breast weight and growth rates of different females broilers strains according to age

\begin{tabular}{ccccccc}
\hline & \multicolumn{6}{c}{ Strain } \\
\cline { 2 - 7 } Age & \multicolumn{2}{c}{ Cobb } & \multicolumn{2}{c}{ Ross } & \multicolumn{2}{c}{ Hubbard } \\
\cline { 2 - 7 } & $\mathrm{BW}^{1}(\mathrm{~g})$ & $\mathrm{GR}^{4}(\mathrm{~g} /$ day $)$ & $\mathrm{BW}^{2}(\mathrm{~g})$ & $\mathrm{GR}(\mathrm{g} /$ day $)$ & $\mathrm{BW}^{3}(\mathrm{~g})$ & $\mathrm{GR}(\mathrm{g} /$ day $)$ \\
\hline 1 & 8.0 & 1.56 & 6.3 & 1.32 & 4.1 & 0.99 \\
7 & 26.4 & 3.91 & 22.6 & 3.58 & 17.8 & 3.21 \\
14 & 65.4 & 7.38 & 59.5 & 7.11 & 52.9 & 7.07 \\
21 & 130.6 & 11.22 & 123.4 & 11.15 & 118.6 & 11.73 \\
28 & 221.1 & 14.45 & 214.3 & 14.64 & 215.6 & 15.78 \\
35 & 330.0 & 16.42 & 325.2 & 16.79 & 335.6 & 18.17 \\
42 & 447.6 & 16.95 & 445.7 & 17.39 & 465.5 & 18.65 \\
49 & 564.5 & 16.27 & 565.5 & 16.68 & 593.1 & 17.59 \\
56 & 673.5 & 14.78 & 677.1 & 15.09 & 709.5 & 15.57 \\
\hline
\end{tabular}

Abbreviations: BW - breast weight; GR - growth rates

${ }^{1} \mathrm{BW}_{\mathrm{t}}=1182.1 . \exp \left(-\exp \left(-0.039 .(\right.\right.$ Age-41.25)) $) ;{ }^{2} \mathrm{BW}_{\mathrm{t}}=1182.1 . \exp \left(-\exp (-0.040 .(\right.$ Age-41.38) $)) ;{ }^{3} \mathrm{BW}_{\mathrm{t}}=1182.1 . \exp (-\exp (-0.043 .(\mathrm{Age}-$ 40.36))); ${ }^{4}$ Calculated by the derivatives of the Gompertz equations.

As with the $\mathrm{BW}$, the models $\omega_{1}, \omega_{2}$ and $\omega_{3}$ did not differ $(\mathrm{P}>0.05)$ from the $\Omega$ model for the TW of the females, with the $\omega_{1}$ model having the smallest residual sums of squares and thus the most appropriate to describe the TW growth (Table 14).

Table 14

Estimates of the values of the parameters of unrestricted $(\Omega)$ and restricted model $\left(\omega_{1}\right.$ to $\left.\omega_{6}\right)$, residuals sums of squares, Chi-square calculated and significance level for the thighs weight of different females broilers strain

\begin{tabular}{|c|c|c|c|c|c|c|c|c|}
\hline \multirow{2}{*}{ Strain } & \multirow{2}{*}{ Parameter } & \multicolumn{7}{|c|}{ Models $^{1}$} \\
\hline & & $\Omega$ & $\omega_{1}$ & $\omega_{2}$ & $\omega_{3}$ & $\omega_{4}$ & $\omega_{5}$ & $\omega_{6}$ \\
\hline \multirow{3}{*}{ Cobb } & $\mathrm{Wm}$ & 432.1 & - & 361.1 & 365.6 & - & - & - \\
\hline & $\mathrm{b}$ & 0.036 & 0.038 & - & 0.041 & 0.045 & - & - \\
\hline & $\mathrm{t}^{*}$ & 42.29 & 40.01 & 37.22 & - & - & 41.07 & - \\
\hline \multirow{3}{*}{ Ross } & $\mathrm{Wm}$ & 345.1 & - & 372.8 & 383.5 & - & - & - \\
\hline & $\mathrm{b}$ & 0.046 & 0.040 & - & 0.041 & 0.048 & - & - \\
\hline & $\mathrm{t}^{*}$ & 34.72 & 38.57 & 36.73 & - & - & 39.77 & - \\
\hline \multirow{3}{*}{ Hubbard } & $\mathrm{Wm}$ & 422.8 & - & 440.8 & 426.7 & - & - & - \\
\hline & $\mathrm{b}$ & 0.044 & 0.047 & - & 0.044 & 0.058 & - & - \\
\hline & $\mathrm{t}^{*}$ & 37.28 & 35.83 & 38.37 & - & - & 37.29 & - \\
\hline \multirow{3}{*}{ Common } & $\mathrm{Wm}$ & - & 399.3 & - & - & 332.6 & 419.3 & 395.8 \\
\hline & $\mathrm{b}$ & - & - & 0.042 & - & - & 0.039 & 0.042 \\
\hline & $\mathrm{t}^{*}$ & - & - & - & 37.53 & 33.35 & - & 37.78 \\
\hline
\end{tabular}


continuation

\begin{tabular}{|c|c|c|c|c|c|c|c|}
\hline $\operatorname{RSS}\left(n \sigma^{2}\right)^{2}$ & 41549.9 & 42219.6 & 42260.8 & 42221.7 & 57830.8 & 49238.4 & 65252.2 \\
\hline$\chi^{2}$ calculated $^{3}$ & & 4.877 & 5.174 & 4.892 & 100.841 & 51.783 & 137.666 \\
\hline$\chi^{2}$ tabulated $^{4}$ & & 5.991 & 5.991 & 5.991 & 9.488 & 9.488 & 12.593 \\
\hline$P\left(\chi^{2} \mathrm{tab}>\chi^{2} \text { calc }\right)^{5}$ & & 0,087 & 0,075 & 0.086 & $<0.001$ & $<0.001$ & $<0.001$ \\
\hline Decision in relation to $\mathrm{H}_{0 \mathrm{i}}$ & & No Reject & No Reject & No Reject & Reject & Reject & Reject \\
\hline
\end{tabular}

Abbreviations: RSS - residuals sums of squares ; $\chi^{2}$ cal - Chi-square calculated; $P$ - significance level

${ }_{1}^{1}$ to ${ }_{6}$ adjusted according hypotheses $\mathrm{H}_{01}$ to $\mathrm{H}_{06}$, respectively; ${ }^{2}$ residuals sums of squares $(\mathrm{n}=305) ;{ }^{3} \chi^{2} \mathrm{calculated}=-\mathrm{n}$. $\ln \left(\mathrm{RSS}_{\Omega} /\right.$

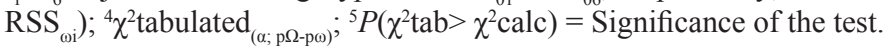

The TW growth curves of the different strains had the same Wm parameter $(\mathrm{Wm}=399.3)$, with the highest $b(0.047 \mathrm{~g} /$ day $/ \mathrm{g})$ for the Hubbard strain, followed by the Ross ( $\mathrm{b}=0.040 \mathrm{~g} / \mathrm{day} / \mathrm{g})$ and Cobb
( $b=0.038 \mathrm{~g} / \mathrm{day} / \mathrm{d}$ ), so that the highest growth rates of the TW cut were seen in the Hubbard females $\left(\mathrm{t}^{*}=35.83\right.$ days) compared to the Ross $\left(\mathrm{t}^{*}=38.57\right.$ days) or the Cobb ( $t^{*}=40.41$ days) birds (Table 15).

Table 15

Estimates of thighs weight and growth rates of different females broilers strains according to age

\begin{tabular}{ccccccc}
\hline & \multicolumn{9}{c}{ Strain } \\
\cline { 2 - 7 } Age & \multicolumn{2}{c}{ Cobb } & \multicolumn{2}{c}{ Ross } & \multicolumn{2}{c}{ Hubbard } \\
\cline { 2 - 7 } & $\mathrm{TW}^{1}(\mathrm{~g})$ & $\mathrm{GR}^{4}(\mathrm{~g} /$ day $)$ & $\mathrm{TW}^{2}(\mathrm{~g})$ & $\mathrm{GR}(\mathrm{g} /$ day $)$ & $\mathrm{TW}^{3}(\mathrm{~g})$ & $\mathrm{GR}(\mathrm{g} /$ day $)$ \\
\hline 1 & 4.1 & 0.72 & 3.7 & 0.69 & 1.8 & 0.46 \\
7 & 12.0 & 1.60 & 11.6 & 1.65 & 8.3 & 1.51 \\
14 & 27.2 & 2.78 & 27.6 & 2.95 & 24.5 & 3.22 \\
21 & 50.9 & 3.99 & 53.0 & 4.28 & 53.6 & 5.06 \\
28 & 82.4 & 4.94 & 86.8 & 5.30 & 94.1 & 6.39 \\
35 & 119.1 & 5.48 & 126.0 & 5.81 & 141.2 & 6.90 \\
42 & 158.0 & 5.57 & 167.0 & 5.82 & 188.9 & 6.64 \\
49 & 196.2 & 5.30 & 206.6 & 5.45 & 233.0 & 5.90 \\
56 & 231.6 & 4.79 & 242.7 & 4.83 & 271.0 & 4.94 \\
\hline
\end{tabular}

Abbreviations: TW - thighs weight; GR - growth rates

${ }^{1} \mathrm{TW}_{\mathrm{t}}=399.3 . \exp \left(-\exp (-0.038 .(\right.$ Age-40.01) $)) ;{ }^{2} \mathrm{TW}_{\mathrm{t}}=399.3 . \exp \left(-\exp (-0.039 .(\right.$ Age-38.57) $)) ;{ }^{3} \mathrm{TW}_{\mathrm{t}}=399.3 . \exp (-\exp (-0.046 .($ Age$35.83))) ;{ }^{4}$ Calculated by the derivatives of the Gompertz equations.

Our results (Tables 12 and 15) indicated that the TW comprised $9.4 \%, 9.7 \%$, and $10.4 \%$ of the FW for the Cobb, Ross and Hubbard strains, respectively at 42 days. The observed differences in the TW of the females of different strains were similar to those seen in the males, with the thigh yield at 42 days for the Hubbard slightly higher $(11.1 \%)$ than for the Cobb (10.2\%) and the Ross (10.3\%). Practically, the females have to be slaughtered later than the males in order to produce cuts of the standard market weight. Therefore, the females are often slaughtered after the inflection point of the growth curves for specific cuts, so it is important to monitor the growth rate (g/ day) of the different parts at advanced ages.

In contrast to the other characteristics evaluated in both sexes, there was no similarity in any of the parameters $\left(\mathrm{Wm}, \mathrm{b}\right.$, or $\left.\mathrm{t}^{*}\right)$ for the DW of the 
Cobb, Ross, and Hubbard females: all the models

unconstrained model $(\Omega)$, and all hypotheses $\left(\mathrm{H}_{01}\right.$ to with restrictions $\left(\omega_{1}\right.$ to $\left.\omega_{6}\right)$ were different from the

$\left.\mathrm{H}_{06}\right)$ were rejected $(\mathrm{P}<0.05)$ (Table 16).

Table 16

Estimates of the values of the parameters of unrestricted $(\Omega)$ and restricted model $\left(\omega_{1}\right.$ to $\left.\omega_{6}\right)$, residuals sums of squares, Chi-square calculated and significance level for the drumsticks weight of different females broilers strains

\begin{tabular}{|c|c|c|c|c|c|c|c|c|}
\hline \multirow{2}{*}{ Strain } & \multirow{2}{*}{ Parameter } & \multicolumn{7}{|c|}{ Models $^{1}$} \\
\hline & & $\Omega$ & $\omega_{1}$ & $\omega_{2}$ & $\omega_{3}$ & $\omega_{4}$ & $\omega_{5}$ & $\omega_{6}$ \\
\hline \multirow{3}{*}{ Cobb } & $\mathrm{Pm}$ & 732.9 & - & 519.2 & 516.7 & - & - & - \\
\hline & $\mathrm{b}$ & 0.028 & 0.034 & - & 0.035 & 0.040 & - & - \\
\hline & $t^{*}$ & 55.78 & 46.21 & 44.75 & - & - & 46.46 & - \\
\hline \multirow{3}{*}{ Ross } & $\mathrm{Pm}$ & 423.0 & - & 489.5 & 511.2 & - & - & - \\
\hline & $\mathrm{b}$ & 0.040 & 0.033 & - & 0.034 & 0.040 & - & - \\
\hline & $\mathrm{t}^{*}$ & 39.11 & 46.48 & 43.32 & - & - & 47.48 & - \\
\hline \multirow{3}{*}{ Hubbard } & $\mathrm{Pm}$ & 554.2 & - & 599.0 & 582.5 & - & - & - \\
\hline & $\mathrm{b}$ & 0.037 & 0.038 & - & 0.036 & 0.045 & - & - \\
\hline & $t^{*}$ & 43.19 & 42.66 & 45.45 & - & - & 44.69 & - \\
\hline \multirow{3}{*}{ Common } & $\mathrm{Pm}$ & - & 543.8 & - & - & 437 & 572.5 & 542.4 \\
\hline & $\mathrm{b}$ & - & - & 0.035 & - & - & 0.034 & 0.035 \\
\hline & $t^{*}$ & - & - & - & 44.62 & 38.799 & - & 44.92 \\
\hline \multicolumn{2}{|c|}{$\operatorname{RSS}\left(n \sigma^{2}\right)^{2}$} & 54691.8 & 56175.2 & 56082 & 56184.4 & 74813 & 61398.4 & 75423.7 \\
\hline \multicolumn{2}{|c|}{$\chi^{2}$ calculated $^{3}$} & & 8.162 & 7.656 & 8.212 & 95.550 & 35.279 & 98.029 \\
\hline \multicolumn{2}{|c|}{$\chi^{2}$ tabulated $^{4}$} & & 5.991 & 5.991 & 5.991 & 9.488 & 9.488 & 12.593 \\
\hline \multicolumn{2}{|c|}{$P\left(\chi^{2} \mathrm{tab}>\chi^{2} \mathrm{calc}\right)^{5}$} & & 0.016 & 0.021 & 0.016 & $<0.001$ & $<0.001$ & $<0.001$ \\
\hline \multicolumn{2}{|c|}{ Decision in relation to $\mathrm{H}_{0 \mathrm{i}}$} & & Reject & Reject & Reject & Reject & Reject & Reject \\
\hline
\end{tabular}

Abbreviations: RSS - residuals sums of squares ; $\chi^{2}$ cal - Chi-square calculated; $P$ - significance level

${ }_{1}^{1}$ to $_{6}$ adjusted according hypotheses $\mathrm{H}_{01}$ to $\mathrm{H}_{06}$, respectively; ${ }^{2}$ residuals sums of squares $(\mathrm{n}=305) ;{ }^{3} \chi^{2}$ calculated $=-\mathrm{n}$.ln $\left(\mathrm{RSS}_{\Omega} /\right.$ $\operatorname{RSS}_{\omega \mathrm{i}} ;{ }^{4} \chi^{2}$ tabulated $_{(\alpha ; \mathrm{p} \Omega \text {-p } \omega)} ;{ }^{5} P\left(\chi^{2} \mathrm{tab}>\chi^{2}\right.$ calc $)=$ Significance of the test.

As the result, the parameters of the DW growth curves for the females were similar to those with individual curves adjusted for each lineage and sex (Table 1). The Cobb females had higher $\mathrm{W}_{\mathrm{m}}(732.9$ $\mathrm{g})$ and lower $\mathrm{b}(0.028 \mathrm{~g} / \mathrm{day} / \mathrm{g})$ than the Ross $\left(\mathrm{W}_{\mathrm{m}}\right.$ $=423.0 \mathrm{~g}$ and $\mathrm{b}=0.040 \mathrm{~g} / \mathrm{day} / \mathrm{g}$ ) and the Hubbard $\left(\mathrm{W}_{\mathrm{m}}=554.2 \mathrm{~g}\right.$ and $\left.\mathrm{b}=0.037 \mathrm{~g} / \mathrm{day} / \mathrm{g}\right)$, so the Cobb females had higher $t^{*}$ (55.6 days) than the Hubbard $\left(t^{*}=43.2\right.$ days $)$ or the Ross females ( $t *=39.1$ days). Thus, drumsticks of the Cobb females developed slower, but with increasing growth rates after 42 days of age, when the growth of this cut decreased in the other strains (Table 17). 
Table 17

Estimates of drumsticks weight and growth rates of different females broiler strains according to age

\begin{tabular}{ccccccc}
\hline \multirow{2}{*}{ Age } & \multicolumn{9}{c}{ Strain } \\
\cline { 2 - 7 } & \multicolumn{2}{c}{ Cobb } & \multicolumn{2}{c}{ Ross } & \multicolumn{2}{c}{ Hubbard } \\
\cline { 2 - 7 } & $\mathrm{DW}^{1}(\mathrm{~g})$ & $\mathrm{GR}^{4}(\mathrm{~g} /$ day $)$ & $\mathrm{DW}^{2}(\mathrm{~g})$ & $\mathrm{GR}(\mathrm{g} /$ day $)$ & $\mathrm{DW}^{3}(\mathrm{~g})$ & $\mathrm{GR}(\mathrm{g} /$ day $)$ \\
\hline 1 & 6.2 & 0.83 & 3.6 & 0.68 & 4.0 & 0.72 \\
7 & 14.6 & 1.60 & 11.4 & 1.65 & 12.2 & 1.72 \\
14 & 29.2 & 2.64 & 27.6 & 3.01 & 29.2 & 3.18 \\
21 & 51.9 & 3.85 & 53.7 & 4.43 & 57.1 & 4.80 \\
28 & 83.1 & 5.07 & 88.9 & 5.55 & 95.9 & 6.22 \\
35 & 122.4 & 6.13 & 130.1 & 6.14 & 143.1 & 7.17 \\
42 & 168.4 & 6.93 & 173.6 & 6.18 & 194.9 & 7.54 \\
49 & 218.8 & 7.41 & 215.7 & 5.81 & 247.4 & 7.38 \\
56 & 271.3 & 7.55 & 254.3 & 5.18 & 297.4 & 6.85 \\
\hline
\end{tabular}

Abbreviations: DW - drumsticks weight; GR - growth rates ${ }^{1} \mathrm{DW}_{\mathrm{t}}=732.9 \cdot \exp \left(-\exp (-0.028 .(\right.$ Age-55.78) $)) ;{ }^{2} \mathrm{DW}_{\mathrm{t}}=423 . \exp \left(-\exp (-0.040 .(\right.$ Age-39.11) $)) ;{ }^{3} \mathrm{DW}_{\mathrm{t}}=554,2 \cdot \exp (-\exp (-0.037 .($ Age$43.19))) ;{ }^{4}$ Calculated by the derivatives of the Gompertz equations.

The results of Tables 12 and 17 indicated that, despite growth rate differences, the relative weights of the DW were similar among strains at 42 days of age, comprising $10.0 \%, 10.1 \%$, and $10.8 \%$ of the FW in the Cobb, Ross and Hubbard strains, respectively. Higher $\mathrm{b}$ values imply stronger growth around the inflection point of the curve, while lower $b$ indicates a more dispersed growth over time (Fialho, 1999). In this context, while strains with higher $\mathrm{b}$ for $\mathrm{a}$ certain characteristic will reach the highest growth rate earlier, this may not translate into higher yields, as has been the case for the DW of females.

It is important to emphasize that a particular characteristic of a strain does not imply a lower slaughter age, since the cut weight achieved at the maximum growth rate may be outside of the market standard. It is thus of paramount importance to understand the kinetics of growth for the different cuts in each strain, so that the appropriate choice can be made for a certain strain or sex. In the present study we focused on the growth of the different strains and sexes. We observed the same pattern for the FW, regardless of sex, with higher Wm and $t^{*}$ for the Hubbard strain followed by the
Cobb and Ross, while the $b$ parameter was common among strains. These results are in agreement with Hancock et al. (1995), who observed similarities for the $b$ parameter of the growth curves for different commercial broiler strains. The effects of the strains on the BW, TW and DW were somewhat different: the Wm was similar for all the strains, so the Hubbard birds had higher $b$ and lower $t^{*}$ when compared with the other strains. When the growth potential of broilers with different genotypes was evaluated, several groups observed changes in the parameters of growth curves over time, especially in the maturity rate; higher maturity rates and time to maturity were explained mainly by the recent genetic improvements (Demuner et al., 2017; Goliomytis, Panopoulou, \& Rogdakis, 2003; Gous et al., 1999; Hancock et al., 1995; Marcato et al., 2008; Sakomura, Gous, Marcato, \& Fernandez, 2011).

Our results indicate that the inflection points of the growth curves for the FW ( $\mathrm{t}^{*}=38$ days for females and $t^{*}=42$ days for males) were higher than those reported by Scheuermann et al. (2003), who observed maximum growth rates at 32.7 and 
34.9 days for females and males respectively. Differences in $t^{*}$ (days) for the BW, TW and DW were also observed, with longer time recorded in the present study compared to data reported by Goliomytis et al. (2003), Sakomura et al. (2011), and Scheuermann et al. (2003). These differences reflect the lower values of the $b$ parameter in the present study, so the point of inflection is reached later for the birds of the Cobb, Ross, and Hubbard strains.

It should be noted that the environmental conditions were suboptimal for the birds in our study due mostly to high temperatures in the shed. It is quite possible that hot environment has prevented the strains from reaching the peak of their genetic potential, explaining the differences in the growth curves between the broilers in the present study and those used in experiments with controlled and non-limiting conditions (Goliomytis et al., 2003; Marcato et al., 2008; Sakomura et al., 2011).

Under heat stress conditions, the growth of a given strain with high growth rates under nonlimiting conditions can be reduced affecting the BW or weight of the other cuts over time.

According to Gous et al. (1999), differences between strains may exist in any situation, and while these differences tend to decrease due to the selection by genetic companies, selected genotypes may become increasingly attuned to a given environment producing strains with genotypespecific requirements for optimal nutrition and enviroment.

\section{Conclusions}

In the environmental conditions described here, the Cobb, Ross and Hubbard strains had different growth parameters. While the Hubbard strain had the highest growth rate and estimated weights, these factors did not necessarily translate into higher yield of cuts or greater profitability of this strain. The optimization of profits will depend on additional factors, for example, the value-added in the cut and the form of commercialization of the product.

\section{Acknowledgments}

ASA Alimentos, CIALNE and Granja Planalto LTDA for the donation of hatching eggs and COAVE. Cnpq for the scolarship.

\section{References}

Aggrey, S. E. (2002). Comparison of three nonlinear and spline regression models for describing chicken growth curves. Poultry Science, 81(12), 1782-1788. doi: $10.1093 / \mathrm{ps} / 81.12 .1782$

Alvares, C. A., Stapez, J. L., Sentelhas, P. C., Gonçalves, J. L. M., \& Sparovek, G. (2013). Koppens's climate classification map for Brazil. Meteorologische Zeitschrift, 22(6), 711-728. doi: 10.1127/09412948/2013/0507

Aviagen. Ross Broiler Pocket Guide. (2015). 131p. Recuperado de http://pt.aviagen.com/assets/Tech_ Center/BB_Resources_Tools/Pocket_Guides/RossBroiler-Pocket-Guide-2015-EN.pdf

Cobb. Guia de manejo para frangos de corte cobb 500. (2008). Recuperado de https://wp.ufpel.edu.br/ avicultura/files/2012/04/Cobb-Manual-FrangoCorte-BR.pdf

Demuner, L. Suckeveris, D., Muñoz, J., Caetano, V., de Lima Filho, D., \& Faria, D. (2017). Adjustment of growth models in broiler chickens. Pesquisa Agropecuária Brasileira, 52(12), 1241-1252. doi: 10.1590/s0100-204x2017001200013.

Fialho, F. B. (1999). Interpretação da curva de crescimento de Gompertz. (Comunicado Técnico EMBRAPA). Concórdia: Embrapa. Recuperado de http://cnpsa.embrapa.br/scg/sgc_publicacoes/ $\cot 237 . p d f$

Goliomytis, M., Panopoulou, E., \& Rogdakis, E. (2003). Growth curves for body weight and major component parts, feed consumption, and mortality of male broiler chickens raised to maturity. Poultry Science, 82(7), 1061-1068. doi: 10.1093/ps/82.7.1061

Gompertz, B. (1825). On the nature of the function expressive of the law of human mortality and on a new method of determining the value of life contingencies. Trans. Royal Philosophical Society, 115(9), 513-585. doi: 10.1098/rstl.1825.0026 
Gous, R. M., Moran, E. T., Jr., Stilborn H. R., Bradford, G. D., \& Emmans G. C. (1999). Evaluation of the parameters needed to describe the overall growth, the chemical growth, and the growth of feathers and breast muscles of broilers. Poultry Science, 78(6), 812-821. doi: $10.1093 / \mathrm{ps} / 78.6 .812$

Hancock, C. E., Bradford, G. D., Emmans, G. C., \& Gous, R. M. (1995). The evaluation of the growth parameters of six strains of commercial broiler chickens. British Poultry Science, 36(2), 247-264. doi: 10.1080/00071669508417773

Hubbard. Broiler Management Manual Fast Growth (2016). Retrieved from https://www. hubbardbreeders. com/media/manual_broiler_ management_en__013796700_1441_27062016. pdf

Marcato, S. M., Sakomura, N. K., Munari, D. P., Fernandez, J. B. K., Kawauchi, I. M., \& Bonato, M. A. (2008). Growth and body nutrient deposition of two broiler commercial genetic lines. Brazilian Journal of Poultry Science/Revista Brasileira de Ciência Avícola, 10(2), 117-123. doi: 10.1590/ S1516-635X2008000200007

Regazzi, A. J. (2003). Teste para verificar a igualdade de parâmetros e identidades de modelos de regressão não linear. Revista Ceres, 50(287), 9-26. doi: 10.1590/S0034-737X2010000300005
Rostagno, H. S., Albino, L. F. T., Donzele, J. L., Gomes, P. C., Oliveira, R. F. M., Lopes, D. C.,... Euclides, F. R. (2011). Tabelas brasileiras para aves e suínos, composição de alimentos e exigências nutricionais (3a ed.). Viçosa, MG: Departamento de Zootecnia, Universidade Federal de Viçosa.

Sakomura, N. K., Gous, R. M., Marcato, S. M., \& Fernandez, J. B. K. (2011). A description of the growth of the major body components of 2 broiler chicken strains. Poultry Science, 90(12), 2888- 2896. doi: 10.3382/ps.2011-01602

Sandi, A. J., Santos, J. I., F'., Mieli, M., \& Martins, F. M. (2011). Consolidação do custo do avicultor para a produção de frango de corte "Griller" em Santa Catarina. Concórdia: Embrapa. Comunicado Técnico EMBRAPA. Recuperado de http://infoteca. cnptia.em...oc/920326/1p/publicacao495.pdf

Scheuermann, G. N., Bilgili, S. F., Hess, J. B., \& Mulvaney, D. R. (2003). Breast muscle development in commercial broiler Chickens. Poultry Science, 82(10), 1648-1658. doi: 10.1093/ps/82.10.1648

Tholon, P., \& Queiroz, S. A. (2009). Modelos matemáticos utilizados para descrever curvas de crescimento em aves aplicados ao melhoramento genético animal. Ciência Rural, 39(7), 2261-2269. doi: 10.1590/ S0103-84782009000700050 